\title{
Apocalypse Now: elementos do jornalismo literário na construção cinematográfica da guerra do Vietnã
}

\author{
Autora: Gisele Krodel Rech \\ Orientador: Silvio Ricardo Demétrio
}

Resumo: Um dos filmes de guerra mais cultuados da contemporaneidade, ApocalypseNow apresenta fragmentos da representação da realidade jornalística dentro de sua narrativa cinematográfica. São analogias do livro Despachos do Front, de Michael Herr, livro-reportagem concebido durante o fenômeno do New Journalism, que serviu de apoio ao processo de contextualização da obra-prima de Coppola. A intenção deste trabalho é, pois, analisar a película buscando encontrar nestas analogias elementos textuais da ekphrasis e da fanopeia. Neste processo, no qual a narrativa jornalístico-literária se imbrica na narrativa cinematográfica, a não ficção e a sua representação da realidade surge de modo intermitente em meio à obra ficcional, em um processo conotativo carregado de significações imagéticas, concebidas a partir do poder do texto jornalístico-literário.

Palavras-chave: Jornalismo e literatura, Jornalismo e cinema 


\title{
Apocalypse Now: elements of the Literary Journalism in thecinematographic construction by Vietnan War
}

\begin{abstract}
One of the most revered films of war, Apocalypse Now presents fragments of journalistic representation of reality within a narrative film. They are analogies of the book Dispatches, by Michael Herr, book from the New Journalism phenomenon, which served to support the contextualization of Coppola's masterpiece process. The intention of this paper is therefore analise the film seeking to find in these analogies textual elements of ekphrasis and fanopeia. In this process, in which the literary journalism narrative is enmeshed in film narrative, non fiction and representation of reality arises intermittently through the fictional work, in a process fraught with imagetic connotative meanings, designed from the power of text of literary journalism.
\end{abstract}

Keywords: Literature and journalism, Jornalism and motion pictures

Dissertação completa disponível em: http://www.bibliotecadigital.uel.br/ document/?code $=$ vtls000194636 